\title{
РИТОРИЧНІ ФІГУРИ НА ГЕОПОЛІТИЧНІЙ ШАХІВНИЦІ: ТРОПОЛОГІЧНО-СИМВОЛІЧНІ РЕСУРСИ В АНАЛІЗІ МІЖНАРОДНОГО КОНФЛІКТУ
}

\author{
Людмила Павлюк \\ Львівський національний університет імені Івана Франка, \\ вул. Генерала Чупринки, 49, 79044, Львів, Україна, \\ e-mail:pavlyukl@yahoo.com \\ https://orcid.org/0000-0001-8811-3322
}

Автор досліджує експресивні мовні форми у мас-медійному дискурсі аналізу воєнного конфлікту, опираючись на поняття «сценарію» як форми організації знань про ситуацію та контекст протистояння. Виокремлено основні тематичні й функціональні групи образних засобів, за допомогою яких міжнародні та українські медіадискурси відтворюють геостратегічні інтереси учасників боротьби, впливаючи на сприйняття аудиторії та перспективу ухвалення рішень.

Ключові слова: політичний дискурс мас-медіа, інформаційна війна, риторика пропаганди, репрезентація конфлікту, когнітивна схема, сценарій, тропи, фігури, концептуальна метафора, евфемізми.

Слова, вжиті в переносному значенні, так само як і логіко-структурні засоби виразності, - це традиційний ресурс впливу у сценаріях боротьби інтересів та їхніх репрезентацій у медіа. Закономірно, що тропологічний потенціал масової комунікації завжди привертав увагу дослідників. Грунтовні праці висвітлюють проблематику політичної метафори в медіадискурсі [3; 12], а у контексті гібридної війни набуло актуальності явище евфемізації [10]. Однак аналіз експресивних означників у дискурсі репрезентацій воєнного конфлікту є новою дослідницькою темою, до розгляду якої долучається ця стаття, присвячена особливостям фігуральних компонентів риторики у зв’язку зі спрямованістю сучасних політичних і мілітарних геостратегій.

Методологічні інструменти для осмислення експресивно-образного компоненту конфліктної комунікації розробляє як класична риторика, для якої тропи й фігури - традиційний об'єкт інтересу, так і сучасні когнітивно-прагматичні напрями, які трактують лінгвістичні явища у тісному зв'язку зі «сферами буття». Когнітивний підхід у студіях тропологічних засобів мови, поштовхом до розвитку якого стала відома праця Дж. Лакоффа і М. Джонсона «Метафори, якими ми живемо» [16], пропонує розглядати метафору як ментальну схему й засіб концептуалізації соціального світу і таким чином дає лінгвістиці додаткові можливості для розуміння сутності «симетрій» між мовою і життям соціуму.

(С Павлюк Л., 2019 
Переосмислення метафори в риториці аналізу конфлікту особливо актуальне, оскільки експресивно-виразові інструменти цього виду дискурсу безпосередньо залучені до розв'язання стратегічних завдань, формують мережу соціокультурних концептів і слугують емоційними маркерами сценарію - основної робочої одиниці аналізу в когнітивному підході. 3 погляду завдань сценарію метафора - не оздоба, а органічний компонент системи аргументації. Якщо ідеться про системний розгляд засобів персвазії в аналітичному тексті, то не лише метафоричні, а й раціонально-логічні аргументативні складники мас-медійного наративу про конфлікт варто інтерпретувати в когнітивних термінах - добору, корекції і зміни сценаріїв.

Типовою концептуальною метафорою в розумінні Дж. Лакоффа й М. Джонсона $є$ вислів «геополітична шахівниця», використаний у заголовку цієї статті. За фактичним походженням це парафраз, переформульований варіант ключового образу відомої книги 3. Бжезинського «Велика шахівниця. Американська першість та їі стратегічні імперативи» [14] (власне, радше семантична, аніж ідеологічна алюзія до «прототипної» книги). Розширення метафори «шахівниці» в назві статті полягає у додаванні терміна «фігури», а трансформація первинного образу - у зіставленні кліше «риторичні фігури» й «шахові фігури», що створює певний ефект каламбуру, гри слів, але також має функцію змістового «доважку». Якщо метафора «шахові фігури» стосується усіх можливих інструментів геополітики, то терміносполука «риторичні фігури» у властивому сенсі означує мовні інструменти впливу на масову свідомість.

3’ява книги про події на політичній сцені-«шахівниці» у свій час підкреслила практично універсальну застосовність ідеї гри для соціального аналізу. Серед родових груп метафор, що їх використовують медіа, зокрема й міжнародні медіа, для окреслення рамок сценарію теперішньої російсько-української війни, образ «гри» $€$ одним із найбільш поширених макро-фреймів. Звичними атрибутами у медійно-риторичній репрезентації конфлікту виступають загальномовні метафоричні означники «гри як такої» - «гравиі», театральної гри - «актори», азартних ігор - «ставки y грі» тощо. Окрім того, під метафоричною рубрикою «гри» з’являється багато індивідуальних, нестандартних сценаріїв. За допомогою цієї тематичної транспозиції автори намагаються знайти відповіді на вельми серйозні запитання: Про який вид гри йдеться? Що говорить гра про наміри учасників? Що собою становить гравець із російського боку? Наскільки схильний дотримуватися правил? Які результати цієї гри? Таким чином, різні аспекти метафоричного сценарію з різних боків віддзеркалюють сутність того, що відбувається.

Варто зазначити, що саме поняття гри є дещо евфемістичним, тобто пом'якшувально-ухильним з огляду на дійсність реальних воєнних подій. Війна - це в принципі анти-гра. Образ ігор «з доброю репутацією» ще більш евфемізує іміджі усіх причетних до сценарію. Чимало закордонних аналітиків, особливо на початку розгортання воєнної агресії Росії, намагалися інтерпретувати дії Кремля, вдаючись до образу гри в шахи. Це свідомо чи несвідомою раціоналізувало поведінку Путіна, а до певної міри і виправдовувало, хоча б через те, що з такого погляду російський президент виступає у рольовій позиції «гравця-стратега», а не кримінального злочинця. Зате у пізніших гротескно-негаційних варіантах шахова метафора підкреслює брутальне ставлення кремлівського правителя до міжнародного права, його зневагу до норм коректності та спроб іноземних партнерів грати в «ігри» на раціональній основі: «(Путін) ...змів усі фігури зі столу і вдарив весь світ дошкою по голові, анек- 
ПавлюкЛ

сувавши Крим, розв'язавщи війну на сході Украӥни і налагодивши свою злочинну пропагандистську машину на відверто фашистський лад» [9].

Більш психологічно вмотивованим щодо відтворення суті міждержавних стосунків, які набувають конфліктних форм через агресивну політику одного з учасників, є образ іншого типу ігор - картярських. У термінах картярської гри, Путін не гребує шулерськими методами, а також блефує, тобто вдає, що виступає із сильних позицій, маючи добрі карти. На думку Г. Каспарова, прийоми гри в покер давали змогу російському президентові отримувати очікуване через нерішучість світових гравців: «А навпроти (Путіна) в грі сидять люди, які при першому підвищенні ставок, скидають карти, незалежно від того, які карти у них в руках» [8]. У доповнення до маніпуляцій із картами, Кремль нав’язує світові іще більш ризиковану забаву, відому як «російська рулетка», що передбачає авантюризм великих ставок і повсякчасну загрозу гравцям. Реальний зміст гри в геополітичну рулетку розкриває доданий атрибутив «ядерна». Образ «ядерної рулетки» означає залякування й примушування до поступок: «Путін веде себе на міжнародній арені як божевільний, $i$ його погрози ядерною зброєю схожі на виклик демократичному Заходу зіграти з Москвою $y$ «російську рулетку» [4]. Таким чином через посередництво метафор гри дискурс аналізу конфлікту здійснює моніторинг безпекової ситуації у світі. Градація форм гри за ознакою доданого ризику «шахи - покер - рулетка» є тією концептуальною рамкою, яка підкреслює зростання рівнів загроз на глобальній сцені.

Характерно, що геостратегічний дискурс часто показує нахабну і нечесну гру Росії як таку, що нав’язана Заходові. А неохочу, інертну, поступливу реакцію світової спільноти на агресивно-маніпулятивний натиск пояснює метафоричний фрейм «піддавки»: «Захід, не знаючи, як поводитися з Росією і остерігаючись їі образ, погодився грати з нею в піддавки» [11]. Помітне наростання розгубленості у стосунках міжнародних акторів віддзеркалила метафора «головоломки», взята за основу назви доповіді для 55-ї мюнхенської конференції із безпеки 2019 року. У контексті «великих $і$ малих криз» (насправді - воєн), згадана транспозиція виконує звичну функцію евфемізму, причому - як свідчить супровідна метафора «підбирання деталей» - із відтінком непевності щодо ролей і зобов’язань міжнародних інститутів: «Як завжди конферениії передувала аналітична доповідь Munich Security Report nро ситуачію з безпекою в світі. У нинішньому роиі вона називається «Велика головоломка: хто підбере деталі?» [2].

Метафори «гри» важливі для розуміння командно-змагальних засад функціонування соціуму. Але безперечно, цей образ є не єдиною рамкою, що програмує спосіб розуміння конфлікту. Образні визначення на основі інших сценаріїв так само привертають увагу до основоположних, у тому числі й «конфліктогенних» соціальних атрибутів. Природними для інтерпретації розвитку спільнот завжди були органічні метафори - народження, зростання, занепаду, як і різноманітні характеристики фізичних станів на бінарній осі «норма» - «патологія». Оскільки у випадку воєнних дій ідеться про крайнє загострення суперечностей і спробу розв'язати їх силовими засобами, то актуальними в репрезентаціях такої екстремної форми конфлікту стають оцінки в термінах деструкцій соціального «організму». На означуванні клінічних станів і ресурсів для «терапії» спеціалізується медична метафора, з усім їі розмаїттям видів і тематичних «файлів»: «Донбас треба очистити й вилікувати» (О. Степова), «гангрена кримської неправди» (В. Портников) «геополітична 
«біла гарячка» Москви» (В. Каспрук). Часто у публіцистичній діагностиці автори використовують медичний термін «синдром» (сукупність ознак патології) у поєднанні $з$ назвою геополітичного симптому-символу: «веймарський синдром», «синдром Бісмарка», «мюнхенський синдром».

У когнітивних моделях риторичної комунікації, насамперед образних одиниць дискурсу, є два важливі компоненти - власне засоби означування та об'єкти, що підлягають означуванню. Логіка когнітивного підходу передбачає уважне ставлення до фрагментів реальності, які стають змістовими «екранами» для транспозицій. Отож у наступному викладі матеріалу прослідкуємо, які політичні реалії описані в метафоричних термінах, відзначивши ті клітинки «шахівниці», що мають вагу для комплексного аналізу сценарію конфлікту. Для цілісного бачення стратегії опору країни, яка зазнала нападу й агресії, варто опертися на засадниче (і для політології, і для дискурсного аналізу в традиції М. Фуко) поняття «влади», виокремивши такі іiї осередки, важливі з огляду на роль у сценаріях конфлікту, як законодавча, судова, інформачійна, економічна, військова. Ці типи влади репрезентують державу як сторону конфлікту, а також є структурними характеристиками усієї акумульованої політичної потуги міжнародної спільноти. Зрозуміло, що діяльність «четвертої» влади в час міждержавного конфлікту реалізовується у форматі інформаційної війни. Окрім того, ідею впливовості інформації доповнює уявлення про «п'яту владу», тобто роль експертів і аналітичних центрів. Поширеним також $\epsilon$ поняття «м'яка влада», що підкреслює впливовість культурних ресурсів, як і небезпеку їхнього впливу в час воєнного протистояння, адже суб'єкти такої влади позиціонують себе як позаполітичні, і в багатьох випадках саме так сприймаються у свідомості реципієнтів, але виконують функцію «троянського коня» вартостей ворожої держави. Так, російська «м'яка влада» усвідомлено формує в зарубіжних аудиторіях прошарок «корисних idiomiв», які вважають себе симпатиками культури Росії, не бажаючи усвідомлювати політичних наслідків дій її керівництва.

Оскільки російсько-український конфлікт є асиметричним за ресурсною основою, а до того ж супроводжується порушенням великої кількості міжнародних угод, його вислід великою мірою залежить від риторики й прагматики у політично-дипломатичній сфері: певним чином - від двосторонньої комунікації (обмін нотами, заявами), а ще більшою мірою - від результатів перемовин за участю глобальних лідерів та позиції міжнародних зібрань. Саме міжнародні гравці тримають у руках ключі до впливу на агресора, раз по раз сигналізуючи про перспективу обмежувальних заходів, метафорично означену як «встановлення червоних ліній». Теоретично вагомим інструментом миротворчої діяльності мало би бути обговорення конфлікту на європейських платформах, а також в Організації Об'єднаних Націй. Але більшість інституцій, попри напругу баталій («дипломатичних війн») на своїх сценах, не виходить за рамки ухвалювання декларацій і не має зобов'язувальних інструментів для порушників правил глобального добросусідства. Рішення міжнародних зібрань у задоволенні запитів української сторони часто виявляються нерадикальними, компромісними ще й тому, що заради цих компромісів працює російська дипломатична служба й зовнішня пропаганда, висуваючи найабсурдніші формулювання, щоб згодом досягти поступок для себе.

На 73-й сесії Генеральної асамблеї ООН у вересні 2018 року співробітникам Секретаріату з прав людини довелося спілкуватися із «колегами», «російськими 
правозахисниками», які насправді були «відповідальними» за ігнорування прав громадян на окупованих територіях: «Це чуже ім'я [правозахисник] співробітники РІА Новости навіщось присвоїли Александру Молохову, чия посада називається «керівник робочої групи з міжнародно-правових питань при постійному представництві республіки при президентові». Тобто чиновник окупаційної адміністрації, прикомандируваний до ставки верховного окупанта» [13]. Автор фактично демаскує два рівні неадекватності означників - «ушляхетнювальний» евфемізм («правозахисник») та евфемізм-офіційний термін («координатор з міжнародно-правових питань»), протиставляючи їм реальне трактування ролі - «представник окупаційної влади». Характерно, що згадані «правозахисники» прибули в ООН для того, щоб «поскаржитися на санкції США і Євросоюзу проти Росії і конкретно проти окупаційної адміністрації Криму», як і не менш симптоматично, що врешті-решт чиновники Секретаріату пішли на поступки російській делегації у питанні права виступу [13].

Тактика прямої анексії в мілітарно-політичних діях, «відтискання» в економічній сфері та пропагандистський натиск в зовнішній інформаційній політиці виявляються цілковито корелятивними методами російської «геополітики». Відповідальні представники міжнародної спільноти дедалі більше усвідомлюють загрози агресивних перемовних практик і чинять опір ідеології Кремля та розширенню впливу його агентів. Критична позиція політиків, які засвоїли уроки спілкування з РФ, стає на заваді просуванню російських кандидатур на керівні посади в міжнародних організаціях. Окремі випадки такого запобігання кадровій експансії залишили для історії виразне риторичне маркування. Наприклад, американські сенатори критику російського кандидата сконцентрували в порівнянні-алегорії: «Обрати генерал-майора Александра Покопчука на посаду президента Інтерполу - иче щчось подібне до того, як запустити лиса в курник» [15].

Інформаційна війна і пропаганда як потужне доповнення до воєнної стратегії РФ (спочатку відносно автономна прелюдія, а в часі бойових дій - १ї прямий акомпанемент) мають свої внутрішні рівні й міжнародну сцену. При транспозитивному означенні масштабу впливів російської пропаганди на внутрішню аудиторію і їі токсичності автори мас-медійних контр-дискурсів традиційно звертаються до образів наркотичної залежності: «Путін збільшуватиме пайку ура-патріотичного героӥну для російського народу» (Т. Возняк). Пропаганда для внутрішнього вжитку, як і для потенційно солідарних груп зі зовнішнього світу, оминає раціональні аргументи, покладається на засоби прямої сугестії і потребує примітивної «наочності». Саме тому їі творці розширюють ресурс символіки, водночас матеріально виразний та ірраціонально-зобов'язувальний. Сенс створення символів - це віднаходження форм, які дають життя ідеям. Коли ідеї нав'язує тоталітарна держава, використання символічних засобів стає максимально утилітарним, а їхній зміст примітивізується до конфірмацій солідарності з режимом. Тотожність символів підкреслює ідентичну політику й світогляд, а обмін монументальними втіленнями тоталітарних ідей виконує функцію прямої експансії, матеріального транспортування ідеології: «Гоблін подарував Асаду копію «пам'ятника ввічливим людям». Цілком логічний подарунок для «русского мира», від одного кривавого режиму - іншому. Ці виродки щзо в Сиріі людей знищують, щзо в Україні. I називають иче - «ввічливістю» [6].

У пошуку засобів означування воєнних стратегій публіцисти звертаються до історичного й географічно «іншокультурного» матеріалу, віднаходячи аналоги й 
прецеденти теперішніх сценаріїв війни в координатах «транстемпорального» геополітичного досвіду. Деякі масштабні образи-історичні транспозиції, як наприклад, порівняння агресії РФ і нацистської Німеччини, пронизують медійний дискурс протягом усього часу оглядів воєнних перипетій, починаючи із 2014 року. Залишається цей макросценарій доповнювати новими епізодами. На думку автора одного 3 медійних описів-компаративів, сучасна Росія подібна до гітлерівського Рейху уже не початкового етапу - часу анексій і завоювань, а пізнього періоду - для якого були характерні внутрішні, хоча й мало помітні ззовні, конфлікти: «Росія все більше нагадує Третій Рейх в 1944-1945 роках, коли його різні «вежі» також вели перемовини Великобританією, США і СРСР, і намагались прибрати Гітлера. Але зовні усе було як зазвичай: Геббельс продовжував базікати як Лавров, $i$ запис у загони гітлерюгенду йшов, як у козаки і в кадетські класи в РФ» [5].

Коли у листопаді 2018 року українські парламентарі готувалися до ухвалення постанови про тимчасовий воєнний стан, як захід у відповідь на посилення агресії РФ і загострення ситуації в Керченькій протоці, медіа й соціальні мережі активно продискутували таке рішення. Частиною публічного діалогу й риторичних обгрунтувань пропонованого кроку стали історичні й культурно-географічні компаративи в аргументативно-легітимаційній функції. По-перше, автори коментарів розглянули українську ситуацію в «рамці» міжнародного досвіду. "Хочу поцікавитися, - писав на своїй сторінці у Фейсбукові Почесний Консул Держави Ізраїль у Західному регіоні України Олег Вишняков, - а чи знають песимісти «пораженці», щуо в Ізраїлі режим надзвичайного стану практично не припинявся з 1948 року? Загроза тероризму стала в Ізраїлі рутиною. Всюди військові й поліщейські, в країні діють ретельно розроблені заходи безпеки і методи контролю». 3 іншого боку, дзеркалом для оцінки рішення слугувала для українських громадян власна історія, із перспективи якої паралелі як покликання на аналогічні випадки в минулому - це й образний ресурс, і практична модель, і спосіб акцентування реальної, сутнісної тяглості традицій: «Рівно 100 років тому, в саме в цеей день - 26 листопада - була підписана Постанова Директорії УНР про воєнний стан, в зв'язку з агресією від Московї та Криворізько-Донбаської республіки, котра існувала в ті часи... 26 листопада 1918 26 листопада 2018. Боротьба продовжується!!! Слава Украӥні!!!» [7].

Із тематикою економічних важелів регулювання конфлікту пов'язані впізнавані тропи, які пояснюють джерела фінансового впливу на зарубіжних політичних акторів, масштаби стимулювання, суть взаємних зобов'язань донорів та реципієнтів («фінансовий флірт із РФ», «привілеї для «путінських гаманців», «європейці стали заручниками російських ресурсів», «на російській газовій голці»). За допомогою тропів-афоризмів та авторських парафразів публіцисти поціляють у критичну мішень під назвою «подвійні стандарти європейських політиків»: «B сучасній европейській політиці з кожної сумнівної оборудки проглядають російські вуха. Крим став наріжним каменем, на якому тримається архітектура міжнародного права. Але він одночасно перетворився $і$ на «отруєне яблуко», яке має приспати всю систему європейських иінностей. Таких як демократія, свобода, иінність людського життя, та непохитність права власності. Саме їх воліють не помічати «друзі Путіна» у Європі...» [1]. В аналізові програми санкційного стримування публічний дискурс використовує метафоричні образи, які зауважують слабкість уже впроваджених заходів («санкиії мають «косметичний» характер»), але також і окреслюють перспек- 
тиву посилення економічних обмежень для держави-агресора: «санкиійний Рубікон», «драконівські санкиії», «санкиії з пекла», «готують санкиійну бомбу для Кремля».

Риторика традиційно була впливовою у такій сфері реалізації влади, як юридичні можливості вирішення конфлікту. За аналогією до «інформаційної війни» говорять і про судові, юридичні війни («lawfare»). Для означення збірного образу судових інституцій, зазвичай у зв'язку із нагадуванням про потребу покарати агресора, у дискурсі українських мас-медіа використовують символічні образи «Нюрнберга» й «Гааги». Ці символи мають конкретну фактичну основу. Для історичного Нюрнберзького процесу над керівниками нацистської Німеччини був створений спеціальний орган - Міжнародний військовий трибунал 1945-1946 років. А образові «суду в Гаазі», що його публіцисти наполегливо обіцяють Путінові, символічного змісту надала історія Міжнародного кримінального трибуналу для колишньої Югославії, який виносив вирок особам, відповідальним за порушення міжнародного гуманітарного права у час воєнних конфліктів на Балканах. Окрім того, є сучасні інституції права в Гаазі, що діють на постійній основі, - Міжнародний суд ООН і Міжнародний кримінальний суд, - прямо причетні до розгляду українсько-російського конфлікту. Новини, які медіа приносять із юридичного «фронту», свідчать про те, що російська сторона приготувалася до тривалої софістично-маніпулятивної «облоги» міжнародних інституцій. Її судовий дискурс наводнюють евфемізми, гіперболи, фейки та інші засоби розхитування, розмивання і спотворення суті. Звісно ж український контр-дискурс реагує на це за допомогою фактичних спростувань, а також давно відомої і широко застосовної риторичної процедури корекиї̈ термінів.

Хотілося б вірити, що ця рушниця вистрілить.

Такі види влади, як інформаційна, економічна, юридична, у ситуації реальних воєнних дій стають «співфункціональними» 3 мілітарними стратегіями, працюють синергійно, реалізовуючи оборонні та ідентифікаційно-консолідаційні завдання. Сценарій, який має не лише спільну подієву сцену, а й мету - перемогу, об'єднує учасників і слугує камертоном сенсів для текстів різних типів. Кожна зі сфер, які мають вплив на перебіг подій, пов'язаних із конфліктом, формує власну комунікативну мережу і мапу стратегій, на якій червоними прапорцями можна позначити риторичні фігури, символічні «згущення», конденсовані елементи, що демонструють суть i спрямованість процесів боротьби за незалежність.

Аналіз образів-транспозицій у дискурсі аналізу воєнних сценаріїв, здійснений у структурно-площинному вимірі, відтворює картину подій за сферами буття. Не менш інформативним є огляд експресивних мовних форм у часовому континуумі, що дає змогу зробити висновки про напрям розвитку конфлікту, стан ресурсної бази i перспективи його учасників. Скажімо, медична метафора сигналізує про наростання симптомів деструкції й патологій у свідомості й господарських структурах держави-агресора. Динамічний аналіз метафор із тематичної групи «гри» демонструє, що члени світової спільноти дедалі реалістичніше сприймають політику РФ, ставляться до рішень її керівництва як таких, що створюють системні загрози для світової безпеки.

Експресивно-образні засоби в дискурсі аналізу конфлікту мають і діагностичну, і конструктивну мету. Риторика прямо причетна до медіативної комунікації, яка протистоїть агресії, допомагає уникати небажаних дій, зокрема ескалації воєнного протистояння, - за допомогою перемовин. Тропологічні ресурси належать до ефек- 
тивних знарядь перемовного процесу, що дозволяє мінімізувати наслідки силових дій і досягти вирішення конфлікту.

\section{REFERENCES}

1. Волошина Л. У європейської корупції є кримські таємниці. 16 листопада 2018, https://www.obozrevatel.com/ukr/abroad/u-evropejskoi-koruptsii-e-krimski-taemnitsi. htm

2. Данилишин Б. Міжнародна безпека - на краю прірви. 15 лютого 2019, https:/nv.ua/ ukr/opinion/mizhnarodna-bezpeka-na-krayu-prirvi-50006319.html

3. Дацишин X. Метафора в сучасному українському політичному дискурсі: За матеріалами преси 1995-2002 років: Довідник. Львів: ПАІС, 2004. 260 с.

4. Каспрук В. Чи зіграє Путін у «російську рулетку» 3 Заходом? 11 вересня, 2017, https:/glavcom.ua/columns/kaspruk/chi-zigraje-putin-u-rosiysku-ruletku-zzahodom-436216.html

5. Климовский С. Трамп подал отличную идею. 5 грудня 2018, https://www. obozrevatel.com/abroad/tramp-podal-otlichnuyu-ideyu.htm

6. КРЫМский бандеровец. Новости Крымнаша. До 2014 года я не представлял глубину деградации в России. 17 жовтня 2018, https://www.obozrevatel.com/society/ novosti-kryimnasha-do-2014-goda-ya-ne-predstavlyal-glubinu-degradatsii-v-rossii.htm

7. Неймовірно! Сто років тому день у день Україна змушена була так само вводити воєнний стан у зв'язку з московською агресією. 27 листопада 2018, http://www. vatra.net.ua/nejmovirno-sto-rokiv-tomu-den-u-den-ukrayina-zmushena-buda-taksamo-vvoditi-voyennij-stan-u-zv-yazku-z-moskovskoyu-agresiyeyu/

8. Путін грає з Обамою в покер, а не в шахи, - Каспаров. 31 березня, 2015, https:// ukranews.com/ua/news/321710-putin-graye-z-obamoyu-v-poker-a-ne-v-shakhykasparov

9. Рабинович С. Нефть российской экономике уже не поможет. 25 сентября 2018. https://www.obozrevatel.com/economics/neft-rossijskoj-ekonomike-uzhe-nepomozhet.htm

10. Тараненко О. Евфемізація в українському медіа-дискурсі періоду гібридної війни. Соціальні комунікації: теорія і практика: наук. журнал. Т. 4. К., 2017, С. 19-27

11. Шевцова Л. Приниження держави. 24 січня, 2019, https:/day.kyiv.ua/uk/blog/ polityka/prynyzhennya-derzhavy

12. Яворська Г. Політичний дискурс у добу змін (на прикладі концептуальної метафори міжособистісних взаємин). Філологічний вісник. 2011. №1. С. 1-19.

13. Яковенко И. Путинская империя выставила напоказ все мыслимые пороки. 29 вересня 2018, https://www.obozrevatel.com/abroad/putinskaya-imperiya-vyistavilanapokaz-vse-myislimyie-poroki.htm

14. Brzezinski Zbigniew. The Grand Chessboard: American Primacy and Its Geostrategic Imperatives. Basic Books, 1998, 240 p.

15. Keller Megan, Senators push back on Russian official's candidacy for Interpol president. November 20, 2018, https://thehill.com/homenews/senate/417639-us-senators-demandtrump-administration-oppose-russian-officials-candidacy

16. Lakoff G., Johnson M. Metaphors We Live By. Chicago: Un-ty of Chicago Press, 1980. 


\title{
RHETORICAL FIGURES ON GEOPOLITICAL «CHESSBOARD»: TROPOLOGY AND SYMBOLIC RESOURCES IN THE ANALYSIS OF INTERSTATE CONFLICT
}

\author{
Lyudmyla Pavlyuk \\ Ivan Franko National University of Lviv, \\ Generala Chuprynky Str., 49, 79044, Lviv, Ukraine \\ e-mail:pavlyukl@yahoo.com \\ https://orcid.org/0000-0001-8811-3322
}

The article studies rhetorical expressive means in the discourses that analyze militarypolitical conflict between Russia and Ukraine within the context of its global hybrid «extension» and the feedback from the international community. It describes various thematic and functional groups of tropes and figures that are instrumental in representation of geostrategic interests and determine the prospect of decision-making and finding solutions to the conflict.

The main object of analysis is relationship between selective strategies of the authors that describe scenarios of war and pragmatic objectives of these presentations relating to the their role in information wars and rhetoric of propaganda. The study focuses on explanation of particular tropes in connection to certain fragments of the scenario and also reconstructs the networks of tropes within «pragmatic spheres» that fulfill the task of resisting aggression and countering disinformation.

In dealing with linguistic material, the author applies concepts and approaches of cognitive linguistic, in particular the theory of frame as a model of representation and cognitive interpretation of metaphor that explains how tropes conceptualize social knowledge and shape attitudes. The implications of the metaphoric scenarios surrounding the concept of «game» can have either legitimizing or critical practical intention behind the trope.

The workings of rhetorical means are shown in relation to different layers and types of power that forms the cumulative potential for the resilience of the state. The article focuses on the synergetic contribution of information, diplomatic, economic, and judicial power into the implementation of the society's goals in the struggle for independence. It explains how different types of power are accessed from metaphorical perspective and what means they use in the conditions of military mobilization and consolidation of identity.

Key words: political discourse in mass media, information war, rhetoric of propaganda, representation of conflict, cognitive scheme, scenario, tropes, figures, conceptual metaphor, euphemisms. 